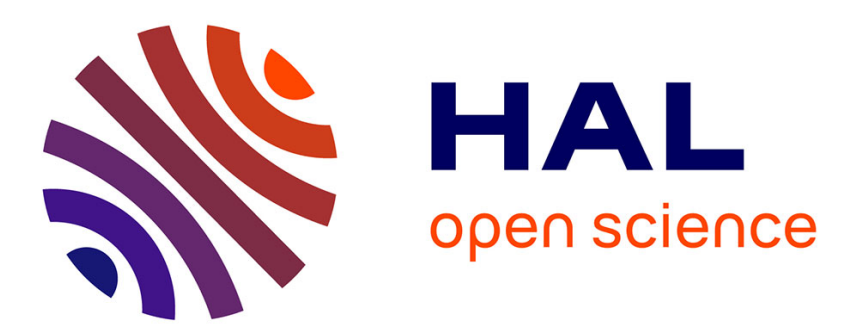

\title{
Tracking Animal Reservoirs of Pathogenic Leptospira: The Right Test for the Right Claim
}

Yann Gomard, Koussay Dellagi, Steven Goodman, Patrick Mavingui, Pablo

Tortosa

\section{- To cite this version:}

Yann Gomard, Koussay Dellagi, Steven Goodman, Patrick Mavingui, Pablo Tortosa. Tracking Animal Reservoirs of Pathogenic Leptospira: The Right Test for the Right Claim. Tropical Medicine and Infectious Disease, 2021, 6 (4), pp.205. 10.3390/tropicalmed6040205 . hal-03481570

\author{
HAL Id: hal-03481570 \\ https://hal.science/hal-03481570
}

Submitted on 16 Dec 2021

HAL is a multi-disciplinary open access archive for the deposit and dissemination of scientific research documents, whether they are published or not. The documents may come from teaching and research institutions in France or abroad, or from public or private research centers.
L'archive ouverte pluridisciplinaire HAL, est destinée au dépôt et à la diffusion de documents scientifiques de niveau recherche, publiés ou non, émanant des établissements d'enseignement et de recherche français ou étrangers, des laboratoires publics ou privés.

\section{(c)(1)}

Distributed under a Creative Commons Attribution| 4.0 International License 


\title{
Article
}

\section{Tracking Animal Reservoirs of Pathogenic Leptospira: The Right Test for the Right Claim}

\author{
Yann Gomard $^{1}$, Koussay Dellagi ${ }^{2}\left(\right.$, , Steven M. Goodman ${ }^{3,4}{ }^{\oplus}$, Patrick Mavingui ${ }^{1}$ and Pablo Tortosa ${ }^{1, *(\mathbb{C})}$ \\ 1 Unité Mixte de Recherche Processus Infectieux en Milieu Insulaire Tropical (UMR PIMIT), \\ Université de La Réunion, CNRS 9192, INSERM U1187, IRD 249, Plateforme Technologique CYROI, \\ 2 Rue Maxime Rivière, 97490 Sainte-Clotilde, France; yann.gomard@gmail.com (Y.G.); \\ patrick.mavingui@cnrs.fr (P.M.) \\ 2 International Department, Institut Pasteur, 75015 Paris, France; koussay.dellagi@pasteur.fr \\ 3 Field Museum of Natural History, 1400 South Lake Shore Drive, Chicago, IL 60605, USA; \\ sgoodman@fieldmuseum.org \\ 4 Association Vahatra, BP 3972, Antananarivo 101, Madagascar \\ * Correspondence: pablo.tortosa@univ-reunion.fr
}

Citation: Gomard, Y.; Dellagi, K.; Goodman, S.M.; Mavingui, P.;

Tortosa, P. Tracking Animal

Reservoirs of Pathogenic Leptospira: The Right Test for the Right Claim. Trop. Med. Infect. Dis. 2021, 6, 205. https://doi.org/10.3390/ tropicalmed6040205

Academic Editor: Mark Robinson

Received: 9 November 2021

Accepted: 24 November 2021

Published: 30 November 2021

Publisher's Note: MDPI stays neutral with regard to jurisdictional claims in published maps and institutional affiliations.

Copyright: (c) 2021 by the authors. Licensee MDPI, Basel, Switzerland. This article is an open access article distributed under the terms and conditions of the Creative Commons Attribution (CC BY) license (https:/ / creativecommons.org/licenses/by/ $4.0 /)$.

\begin{abstract}
Leptospirosis is the most prevalent bacterial zoonosis worldwide and, in this context, has been extensively investigated through the One Health framework. Diagnosis of human leptospirosis includes molecular and serological tools, with the serological Microscopic Agglutination Test (MAT) still being considered as the gold standard. Mammals acting as reservoirs of the pathogen include species or populations that are able to maintain chronic infection and shed the bacteria via their urine into the environment. Animals infected by Leptospira are often identified using the same diagnosis tool as in humans, i.e., serological MAT. However, this tool may lead to misinterpretations as it can signal previous infection but does not provide accurate information regarding the capacity of animals to maintain chronic infection and, hence, participate in the transmission cycle. We employ in this paper previously published data and present original results on introduced and endemic small mammals from Indian Ocean islands to show that MAT should not be used for the identification of Leptospira reservoirs. By contrast, serological data are informative on the level of exposure of animals living in a specific environment. We present a sequential methodology to investigate human leptospirosis in the One Health framework that associates molecular detection in humans and animals, together with MAT of human samples using Leptospira isolates obtained from reservoir animals occurring in the same environment.
\end{abstract}

Keywords: Leptospira; animal reservoir; One Health; MAT

\section{Introduction}

Leptospirosis is claimed as the most widespread bacterial zoonosis worldwide causing over 1 million human cases and nearly 60,000 deaths annually [1]. Despite its medical and veterinary importance, the burden of the disease remains underestimated in numerous countries, stimulating epidemiological investigations conducted in the One Health framework and aiming at identifying the major drivers of the disease [2-4]. Leptospirosis is caused by pathogenic bacteria belonging to the genus Leptospira (family Leptospiraceae), which have been historically classified using antigenic determinants through the Microscopic Agglutination Test (MAT) [5] and Co-Agglutination Absorption Technique (CAAT), allowing researchers to define over 20 serogroups and 300 serovars [6,7]. Molecular tools have been more recently developed and have revealed a higher genetic diversity of Leptospira than previously recognized [7-9] with several additional species being discovered using genomic approaches [10,11].

The main biological cycle of pathogenic Leptospira involves wild or domestic animals acting as reservoirs that shed the bacteria via their urine into the environment [12]. Humans 
get mostly (but not only, see [13]) infected through indirect contact with a contaminated environment. Although virtually all mammal species can get infected by pathogenic Leptopsira, some requirements are needed to consider them as reservoirs, particularly their ability to support chronic maintenance of the bacteria in their kidneys [14]; and indeed, only a limited number of species definitively fulfill this criteria. Rodents are considered as the main reservoirs, but other mammals, such as bats [15] and introduced $[16,17]$ or endemic $[18,19]$ small terrestrial mammals and cattle [20,21], have been identified as important reservoirs of Leptospira. The multiplication of pathogenic bacteria in animal reservoirs has been examined in experimental infections of mice under laboratory-controlled conditions [22]. Using bioluminescent Leptospira, authors have shown that a systemic infection associated with weight loss can occur within three days following intra-peritoneal injection. Thereafter, within a week, bacteria become rapidly invisible, while animals return to a body weight that is hardly distinguishable from that of control animals. Subsequently, a bioluminescent signal of Leptospira appears in the kidneys where bacteria actively divide leading to a glowing signal persisting for months and, at the same time, systemic infection has apparently vanished [22].

Hence, the fate of pathogenic Leptospira appears to be different in reservoir and incidental hosts, with a systemic infection followed by renal colonization in the former, contrasting with an absence of renal colonization in the latter. Discriminating between reservoir and incidental hosts may be not that clear cut, as it depends on different parameters [23]. Indeed, in experimental infections, the survival of infected animals and shedding of bacteria depend on the bacterial strains, the infecting bacterial dose, the considered vertebrate species, as well as the routes of infection [22,24-26]. For instance, though experimental infection of golden hamsters (Mesocricetus auratus) induces acute lethal infection in most animals, it may lead to chronic shedding in the few animals surviving the infection [27]. Of important note is that the colonization of renal tubules by leptospires, which is a characteristic of animal reservoirs, has a considerable immunological consequence: pathogenic Leptospira organized in biofilms in the lumen of renal tubules [28] remain hidden from the immune system and animals may not maintain in the long term the antibody responses elicited following acute infection. The duration of seropositivity is not clear and may not be for the life of the animal [29]. As a consequence, the immunological signature detected in an animal reservoir may not reflect the Leptospira species that are actually chronically shed by these animals.

Beside its use in Leptospira classification, MAT is considered as the reference serodiagnostic test for leptospirosis in incidental hosts (humans and domestic animals), as it allows for detecting host antibodies that attest to current, recent, or past infections $[6,30]$. MAT has also been widely used for the investigation of animal reservoirs [31-35], but some studies indicate that MAT does not definitively identify the carrier status of a given animal species [36-39]. In the present work, we further support these latter observations and argue that the use of MAT may lead to incorrect conclusions regarding the role of investigated animal species as reservoirs and, hence, the importance of such animal species in the epidemiology of human forms of leptospirosis.

To support our purposes, we focused on mammal species known as pathogenic Leptospira reservoirs on southwestern Indian Ocean (SWIO) islands. This region is home to a wide diversity of mammals, including many endemic, as well as introduced rodents (family Muridae) and shrews (family Soricidae). The typing of Leptospira excreted by mammals in this region has demonstrated high levels of Leptospira-host specificity [18,19,40,41]. Indeed, the region is home to a large diversity of bats from seven different families that represent multiple colonizations of the region. Moreover, on Madagascar, endemic terrestrial mammals of the family Tenrecidae and family Nesomyidae (each representing separate colonization events and subsequent adaptive radiations), were shown to be the reservoirs of specific pathogenic Leptospira, providing interesting ecological circumstances to address the power of MAT for investigating leptospirosis epidemiology. 
Three animal species from the SWIO region, known to host distinct bacterial lineages/species of Leptospira, were included in the present investigation. Using published molecular and serological data together with original results, we demonstrate that Leptospira serological signatures are not necessarily connected to the Leptospira excreted by animal reservoirs. We demonstrate the shortfalls of only using MAT alone for the identification of Leptospira animal reservoirs and discuss the utility of MAT for clarifying leptospirosis epidemiology.

\section{Materials and Methods}

\subsection{Ethical Considerations}

All biological material screened in the present study was sampled in the context of a research program for which sampling methods, permit numbers, and IACUC acceptance have been presented elsewhere [40].

\subsection{Animal Sampling, Leptospira Serological, and Molecular Data}

The three mammal species from the SWIO analyzed in the study include the following: Mormopterus acetabulosus (Molossidae), an insectivorous bat species endemic to Mauritius; Tenrec ecaudatus (Tenrecidae), an omnivorous terrestrial mammal species endemic to Madagascar and introduced to several SWIO islands, including La Réunion and Mayotte; and an invasive rodent species, Rattus rattus (Muridae) sampled both on La Réunion and on Mayotte (Tables 1 and S1). All these species were previously investigated for Leptospira infection through molecular and/or serological methods by different research groups $[19,21,35,40,42,43]$. In addition, we produced serological data through MAT for $M$. acetabulosus samples. The same individual specimens were previously screened for Leptospira infection through molecular methods, and the sampling method for these animals is detailed in a published article [40]. The MAT was based on a panel of 18 Leptospira strains allowing for the screening of all serogroups recently reported on both human cases and animals from the Malagasy region. Strains are listed here as Genus species Serogroup/Serovar (type strain): Leptospira biflexa Semaranga/Patoc (Pato I [Paris]), L. borgpetersenii Ballum/Castellonis (Castellon 3), L. borgpetersenii Sejroe/Hardjobovis (Sponselee), L. borgpetersenii Sejroe/Sejroe (M 84), L. borgpetersenii Tarassovi/Tarassovi (Perepelicin), L. interrogans Australis/Australis (Ballico), L. interrogans Autumnalis/Autumnalis (Akiyami A), L. interrogans Bataviae/Bataviae (Van Tienen), L. interrogans Canicola/Canicola (Hond Utrecht IV), L. interrogans Hebdomadis/Hebdomadis (Hebdomadis), L. interrogans Icterohaemorrhagiae/Copenhageni (Wijnberg), L. interrogans Icterohaemorrhagiae/ Icterohaemorrhagiae (Undetermined strain), L. interrogans Pomona/Pomona (Undetermined strain), L. interrogans Pyrogenes/Pyrogenes (Salinem), L. kirschneri Cynopteri/ Cynopteri (3522C), L. kirschneri Grippotyphosa/Grippotyphosa (Moskva V), L. kirschneri Mini/Undetermined serovar (200803703) [35], and L. noguchii Panama/Panama (CZ 214K). Each serum was tested at dilutions ranging from 1:50 to 1:3200 and considered as positive when the MAT titer was $\geq 1: 100$.

Table 1. Animal species used in the present study and the associated publications for Leptospira investigations.

\begin{tabular}{cccc}
\hline Animal Species & Islands & Serological Data & Molecular Data \\
\hline $\begin{array}{c}\text { Mormopterus } \\
\text { acetabulosus }\end{array}$ & Mauritius & Present study & {$[40]$} \\
\hline \multirow{2}{*}{ Tenrec ecaudatus } & Mayotte & NA & {$[19]$} \\
& La Réunion & {$[42]$} & {$[21,42]$} \\
\hline \multirow{2}{*}{ Rattus rattus } & Mayotte & {$[35]$} & {$[19,35]$} \\
& La Réunion & {$[42]$} & {$[21,42]$} \\
\hline
\end{tabular}




\section{Results}

\subsection{Bats}

Serotyping of Mormopterus acetabulosus samples through MAT indicates that $20.0 \%$ $(6 / 30)$ of specimens were seropositive, with sera agglutinating the Panama and Pyrogenes serogroups (Tables 2 and S1). Using nucleic acids extracted from the kidneys of the same individual specimens, Dietrich et al. [40] reported that $73.3 \%(22 / 30)$ of the animals tested positive through real-time polymerase chain reaction (RT-PCR), stressing the poor agreement between MAT and RT-PCR (Kappa test $=0.17$ ). More specifically, the six MATpositive bats were also positive by RT-PCR while, most importantly, $66.6 \%$ of the remaining MAT-negative bats (16/24) tested positive by RT-PCR. The sequencing of RT-PCR-positives specimens (also positive in MAT) confirmed that M. acetabulosus harbors a Leptospira bacterial sequence falling within the Mormopterus-borne Leptospira monophyletic clade embedded in L. borgpetersenii [40] (Table 2).

Table 2. Comparison of serological and molecular Leptospira data obtained from the investigated animal species.

\begin{tabular}{|c|c|c|c|c|c|}
\hline \multirow[b]{2}{*}{ Animal Species } & \multirow[b]{2}{*}{ Islands } & \multicolumn{2}{|c|}{ Serological Data (MAT) } & \multicolumn{2}{|c|}{ Molecular Data (RT PCR) } \\
\hline & & $\begin{array}{c}\text { Positive Animals } \\
(\%)\end{array}$ & $\begin{array}{c}\text { Detected Serogroups } \\
\text { (Titer) }\end{array}$ & Positive Animals (\%) & Leptospira spp. \\
\hline $\begin{array}{l}\text { Mormopterus } \\
\text { acetabulosus }\end{array}$ & Mauritius & $20.0 \%(6 / 30) *$ & $\begin{array}{c}\text { Panama }(1: 100-400) \\
(n=5) * \\
\text { Pyrogenes }(1: 200) \\
(n=1) *\end{array}$ & $\begin{array}{c}73.3 \%(22 / 30) \\
{[40]}\end{array}$ & $\begin{array}{l}L b(n=8) \\
\quad[40]\end{array}$ \\
\hline \multirow[b]{2}{*}{ Tenrec ecaudatus } & Mayotte & $N A$ & $N A$ & $\begin{array}{c}27.0 \%(10 / 37) \\
{[19]}\end{array}$ & $\begin{array}{c}\operatorname{Lm}(n=8) \\
\quad[19]\end{array}$ \\
\hline & La Réunion & $\begin{array}{c}13.2 \%(5 / 38) \\
{[42]}\end{array}$ & $\begin{array}{c}\text { Icterohaemorrhagiae } \\
(1: 200-800)(n=3) \\
\text { Canicola }(1: 100)(n=1) \\
\text { Bataviae }(1: 100)(n=1) \\
{[42]}\end{array}$ & $\begin{array}{c}0.0 \%(0 / 38) \\
{[42]} \\
0.0 \%(0 / 25) \\
{[21]}\end{array}$ & - \\
\hline \multirow[b]{2}{*}{ Rattus rattus } & Mayotte & $\begin{array}{c}11.2 \%(14 / 125) \\
{[35]}\end{array}$ & $\begin{array}{c}\text { Mini }(1: 100-400)(n=7) \\
\text { Pyrogenes }(1: 200)(n=1) \\
\text { Grippotyphosa } \\
(1: 100-1600)(n=3) \\
\text { Co-agglutinations }(n=3) \\
{[35]}\end{array}$ & $\begin{array}{c}29.8 \%(42 / 121) \\
{[35]} \\
15.9 \%(46 / 289) \\
{[19]}\end{array}$ & $\begin{array}{c}L b(n=9), L i \\
(n=7), L k(n=2), \\
\operatorname{Lm}(n=2) \\
{[35]} \\
L b(n=13), L i \\
(n=3), L k(n=5) \\
{[19]}\end{array}$ \\
\hline & La Réunion & $\begin{array}{c}78.8 \%(52 / 66) \\
{[42]}\end{array}$ & $\begin{array}{c}\text { Icterohaemorrhagiae } \\
(1: 100-3200)(n=22) \\
\text { Canicola }(1: 100-400) \\
(n=7) \\
\text { Sejroe }(1: 100-1: 200) \\
(n=2) \\
\text { Mini }(1: 100)(n=1) \\
\text { Cynopteri }(1: 3200) \\
(n=1) \\
\text { Co-agglutinations } \\
(n=19) \\
{[42]}\end{array}$ & $\begin{array}{c}65.8 \%(50 / 76) \\
{[42]} \\
38.5 \%(214 / 562) \\
{[21]}\end{array}$ & $\begin{array}{c}\operatorname{Li}(n=201) \\
\quad[21]\end{array}$ \\
\hline
\end{tabular}

Lb: L. borgpetersenii, Li: L. interrogans, Lk: l. kirschneri, Lm: L. mayottensis. MAT: Microscopic Agglutination Test, RT PCR: real-time polymerase chain reaction. NA: Not available. *: Original data. 


\subsection{Rats}

Introduced populations of Rattus rattus are present on both Mayotte and La Réunion, but molecular and serological screenings of Leptospira highlight striking differences between these two islands (Table 2). On Mayotte, animal antibodies identified three previously reported serogroups, namely Mini, Pyrogenes, and Grippotyphosa, whereas on La Réunion, the main detected serogroups correspond to Icterohaemorrhagiae, Canicola, Sejroe, Mini, and Cynopteri [35,42]. Molecular investigations of $R$. rattus on both islands revealed sharp inter-island differences, with La Réunion animals harboring strictly L. interrogans [21], while on Mayotte, this rodent may harbor any of four distinct Leptospira species (L. interrogans, L. borgpetersenii, L. kirschneri and L. mayottensis) [19,42].

On La Réunion, a study investigated a human leptospirosis outbreak after a triathlon event. In summary, $10 R$. rattus individuals were trapped a few weeks at the site the sporting event took place, and 5 out of the 10 sampled rats tested positive by PCR using kidney samples. The sequencing of the positive samples revealed only L. interrogans [21,43]; however, two of the PCR-positive specimens were seropositive through MAT, whereas the remaining PCR-positive rats were seronegative.

\subsection{Tenrecs}

On La Réunion, antibodies detecting three serogroups in Tenrec ecaudatus: Icterohaemorrhagiae are usually detected at high titers, while Canicola and Bataviae serogroups are agglutinated at low titers $[34,42]$ (Table 2). Notwithstanding these serological results, T. ecaudatus is not considered as a Leptospira reservoir on that island since renal carriage could not be demonstrated by two independent studies [21,42] (Table 2). This situation contrasts with that on Mayotte, where T. ecaudatus was identified as the reservoir of L. mayottensis, a pathogenic species commonly associated with human leptospirosis on that island [19] (Table 2).

\section{Discussion}

The Microscopic Agglutination Test (MAT) has been, and still is, considered the gold standard for leptospirosis diagnosis in humans. In mammals, a meta-analysis has calculated the mean prevalence of infection using the data published in 300 publications including eight different taxonomic orders [33]. MAT and PCR were given an equivalent weight in that analysis, and the nature of the screened samples, i.e., blood (for MAT and PCR) or kidney/urine (for PCR only) was not taken into consideration. Hence, the discrimination between acute and previous infections in incidental hosts and chronic kidney carriage in true animal reservoirs was not made in that study, while this distinction has been made other studies. In the bat samples screened in the present study, we demonstrate a poor agreement between data generated using serological and molecular analyses. Similar findings were also reported on an Australian fruit bat species, Pteropus alecto (family Pteropodidae) [44], which indicated poor agreement between PCR (kidney detection) and serological data; these results underline that a carrier status for this bat species could not be shown using serology. In Brazil, studies have reported limited agreement or an absence of agreement between PCR (urine detection) and serological results in livestock animals or asymptomatic dogs $[39,45]$. Lastly, a comprehensive study recently reported the visualization, isolation, and genetic characterization of $L$. interrogans from a kidney sample obtained from a seronegative crested porcupine (Hystrix cristata) in Italy [46].

The bat species investigated herein belongs to the genus Mormopterus, which includes two other species in the SWIO region, M. francoismoutoui and M. jugularis, endemic to La Réunion and Madagascar, respectively. Recently, research conducted on these three molossid bats has shown that they shelter pathogenic Leptospira clustering into a single monophyletic L. borgpetersenii clade [40,41]. Interestingly, the screening of M. acetabulosus specimens through MAT reveals that sera agglutinate two distinct serogroups, i.e., Panama, and Pyrogenes. Although there is poor congruence between serogroups and genomospecies, members of Panama serogroup can be found in two species, L. noguchii and 
L. inadai [6], but not in L. borgpetersenii. This suggests that the Panama serogroup signature most likely results from independent systemic infections, which have dissipated without leading to renal colonization.

Although the molecular and serological analyses from Rattus and Tenrec were not all obtained from the same individuals, the results presented herein do not support a clear agreement between molecular and serological data. Interestingly, the investigation of these two mammal genera on Mayotte and La Réunion highlight the importance of independently evaluating the reservoir status of a given mammal species in different settings. Indeed, Rattus is reservoir of different Leptospira species on the two islands. The investigation of Tenrec is even more compelling. While on Mayotte, T. ecaudatus is the carrier of the recently described L. mayottensis, investigations on La Réunion showed that up to $81 \%$ of individual Tenrec were seropositive (mostly reacting against Icterohaemorragiae), but not a single individual showed evidence for chronic kidney infection [21,34,42]. On La Réunion, T. ecaudatus is therefore not a reservoir of Leptospira and the Icterohaemorragiae serogroup seropositivity revealed through MAT should be considered as a mere signature of past infections of these animals exposed to Leptospira present in their environment.

In our tested samples, some individuals were positive through PCR but negative through MAt. These discrepancies may result from past infections and subsequent kidney colonization followed by antibody titer decay and eventual seronegativation, as previously reported in animal reservoirs [29,46] and incidental hosts [47-49]. We propose that conflicting results of known reservoirs, such as bats testing positive through MAT but negative through PCR using kidney tissues and/or urine, are best explained by animals that experienced past infections and for which Leptospira did not colonize the kidneys. This absence of colonization might be related to a low infecting dose and/or from an infecting bacterial genomospecies that is unable to establish persistent renal colonization in a specific vertebrate species. This hypothesis assumes that some putative host-Leptospira molecular determinants may be required for renal colonization and the assumption is supported by the fact that Leptospira from bats and tenrecs were not able to lead to chronic infection in rats [50]. In any case, investigation of the physiological and ecological conditions that determine renal tubule colonization and maintenance of the reservoir status are needed.

Finally, the biological setting of the SWIO islands brings further evidence of problems using MAT for the identification of Leptospira reservoirs. Several studies have used MAT on samples of wild animals to address their role in the epidemiology of leptospirosis. However, even though it is clearly important to address the diversity and intensity of Leptospira exposure in an environmental setting, we emphasize that MAT data from investigated animals cannot provide a robust conclusion regarding their role as a reservoir. Such investigations, carried out in the One Health framework, require bacterial genotyping using kidney or urine samples so that bacteria excreted by mammal reservoirs can be compared to those identified in acute human cases. Only such comprehensive approaches can provide solid conclusions regarding the identification of the main reservoir(s) within an ecosystem and the actual risk for humans [51]. Such information is key to conceiving adapted preventive interventions aiming at reducing human contamination.

\section{Conclusions}

The data presented and discussed herein strongly support that a thorough investigation of leptospirosis following the One Health framework requires (i) PCR screening of urine or kidney tissues from putative animal reservoirs, (ii) isolation of Leptospira from identified reservoirs, and (iii) the inclusion of these isolates in a MAT panel used to screen human sera collected from individuals with activities in the investigated environment. Such analyses allow the identification of animal reservoirs in a specific environmental setting, but also highlight those bacterial species/lineages of major medical concern. 
Supplementary Materials: The following are available online at https: / www.mdpi.com/article/ 10.3390/tropicalmed6040205/s1, Table S1: Details of bat samples, Mormopterus acetabulosus from Mauritius. The table includes the Microscopic Agglutination Test results generated in the present study and molecular data from Dietrich et al. [40]. RT-PCR: Real-Time Polymerase Chain Reaction, CT: Cycle Threshold, FMNH: specimen deposited in the Field Museum of Natural History.

Author Contributions: Conceptualization, K.D., P.M., P.T., methodology, validation and formal analysis: Y.G. and S.M.G., writing and editing: K.D., S.M.G., Y.G., P.M., P.T. All authors have read and agreed to the published version of the manuscript.

Funding: The sampling of Mormopterus acetabulosus on Mauritius was supported by a grant from European Research Development Fund (ERDF) "Pathogènes associés à la Faune Sauvage Océan Indien" \#31189. Original serological data presented in this paper were obtained under a grant from ERDF known as InterregV ECOSPIR “Eco-épidemiologie des leptospires endémiques de l'Océan Indien: des bactéries à risque pour les populations humaines?" (number RE6875).

Institutional Review Board Statement: All animal procedures carried out in this study were performed in accordance with the European Union legislation for the protection of animals used for scientific purposes (Directive 2010/63/EU). On Mauritius sampling and export permits were provided by the National Parks and Conservation Service (NPCS) of the Ministry of Agro Industry and Food Security of Mauritius. The ethical terms of the research protocol were approved by the CYROI Institutional Animal Care and Use Committee (Comité d'Ethique du CYROI n ${ }^{\circ} 114$, IACUC certified by the French Ministry of Higher Education and Research) under accreditation 03387 (LeptOI) and 03584 (BatMan).

Acknowledgments: We are grateful to M. Puttoo and R. Sookhareea on Mauritus (NPCS) for their administrative and field assistance, respectively. This work is dedicated to the memory of A. Michault from the Centre Hospitalier Universitaire (CHU) Saint Pierre, who brought considerable insight into the serological analysis.

Conflicts of Interest: The authors declare no conflict of interest.

\section{References}

1. Costa, F.; Hagan, J.; Calcagno, J.; Kane, M.; Torgerson, P.; Martinez-Silveira, M.S.; Stein, C.; Abela-Ridder, B.; Ko, A.I. Global morbidity and mortality of leptospirosis: A systematic review. PLoS Negl. Trop. Dis. 2015, 9, e0003898. [CrossRef] [PubMed]

2. Vinetz, J.M.; Wilcox, B.A.; Aguirre, A.; Gollin, L.X.; Katz, A.R.; Fujioka, R.S.; Maly, K.; Horwitz, P.; Chang, H. Beyond disciplinary boundaries: Leptospirosis as a model of incorporating transdisciplinary approaches to understand infectious disease emergence. EcoHealth 2005, 2, 291-306. [CrossRef]

3. Allan, K.J.; Biggs, H.M.; Halliday, J.; Kazwala, R.R.; Maro, V.P.; Cleaveland, S.; Crump, J.A. Epidemiology of leptospirosis in Africa: A systematic review of a neglected zoonosis and a paradigm for 'One Health' in Africa. PLoS Negl. Trop. Dis. 2015, 9, e0003899. [CrossRef] [PubMed]

4. Chappel, R.J.; Smythe, L.D. Leptospirosis_importance of a One Health approach. Microbiol. Aust. 2012, 33, 154-156. [CrossRef]

5. Martin, L.; Pettit, A. Sero-Diagnostic de la Spirochaetose Icterohaemorrhagique; Bulletins et Mémoires de la Société Médicale des Hôpitaux de Paris: Paris, France, 1918.

6. Levett, P.N. Leptospirosis. Clin. Microbiol. Rev. 2001, 14, 296-326. [CrossRef]

7. Picardeau, M. Diagnosis and epidemiology of leptospirosis. Méd. Mal. Infect. 2013, 43, 1-9. [CrossRef]

8. Saito, M.; Villanueva, S.Y.A.; Kawamura, Y.; Iida, K.-I.; Tomida, J.; Kanemaru, T.; Kohno, E.; Miyahara, S.; Umeda, A.; Amako, K.; et al. Leptospira idonii sp. nov., isolated from environmental water. Int. J. Syst. Evol. Microbiol. 2013, 63, 2457-2462. [CrossRef] [PubMed]

9. Bourhy, P.; Collet, L.; Brisse, S.; Picardeau, M. Leptospira mayottensis sp. nov., a pathogenic species of the genus Leptospira isolated from humans. Int. J. Syst. Evol. Microbiol. 2014, 64, 4061-4067. [CrossRef] [PubMed]

10. Guglielmini, J.; Bourhy, P.; Schiettekatte, O.; Zinini, F.; Brisse, S.; Picardeau, M. Genus-wide Leptospira core genome multilocus sequence typing for strain taxonomy and global surveillance. PLoS Negl. Trop. Dis. 2019, 13, e0007374. [CrossRef] [PubMed]

11. Vincent, A.T.; Schiettekatte, O.; Goarant, C.; Neela, V.K.; Bernet, E.; Thibeaux, R.; Ismail, N.; Mohd Khalid, M.K.N.; Amran, F.; Masuzawa, T.; et al. Revisiting the taxonomy and evolution of pathogenicity of the genus Leptospira through the prism of genomics. PLoS Negl. Trop. Dis. 2019, 13, e0007270. [CrossRef]

12. Ko, A.I.; Goarant, C.; Picardeau, M. Leptospira: The dawn of the molecular genetics era for an emerging zoonotic pathogen. Nat. Rev. Microbiol. 2009, 7, 736-747. [CrossRef] [PubMed]

13. Bulach, D.; Zuerner, R.L.; Wilson, P.; Seemann, T.; McGrath, A.; Cullen, P.A.; Davis, J.; Johnson, M.; Kuczek, E.; Alt, D.; et al. Genome reduction in Leptospira borgpetersenii reflects limited transmission potential. Proc. Natl. Acad. Sci. USA 2006, 103, 14560-14565. [CrossRef] [PubMed] 
14. Babudieri, B. Animal reservoirs of Leptospires. Ann. N. Y. Acad. Sci. 1958, 70, 393-413. [CrossRef] [PubMed]

15. Dietrich, M.; Wilkinson, D.A.; Benlali, A.; Lagadec, E.; Ramasindrazana, B.; Dellagi, K.; Tortosa, P. Leptospira and paramyxovirus infection dynamics in a bat maternity enlightens pathogen maintenance in wildlife. Environ. Microbiol. 2015, 17, 4280-4289. [CrossRef]

16. Cosson, J.-F.; Picardeau, M.; Mielcarek, M.; Tatard, C.; Chaval, Y.; Suputtamongkol, Y.; Buchy, P.; Jittapalapong, S.; Herbreteau, V.; Morand, S. Epidemiology of Leptospira transmitted by rodents in Southeast Asia. PLoS Negl. Trop. Dis. 2014, 8, e2902. [CrossRef] [PubMed]

17. Costa, F.; Wunder, E.A., Jr.; De Oliveira, D.; Bisht, V.; Rodrigues, G.; Reis, M.G.; Ko, A.I.; Begon, M.; Childs, J.E. Patterns in Leptospira shedding in Norway rats (Rattus norvegicus) from Brazilian slum communities at high risk of disease transmission PLoS Negl. Trop. Dis. 2015, 9, e0003819. [CrossRef]

18. Dietrich, M.; Wilkinson, D.A.; Soarimalala, V.; Goodman, S.M.; Dellagi, K.; Tortosa, P. Diversification of an emerging pathogen in a biodiversity hotspot: Leptospira in endemic small mammals of Madagascar. Mol. Ecol. 2014, 23, 2783-2796. [CrossRef] [PubMed]

19. Lagadec, E.; Gomard, Y.; Le Minter, G.; Cordonin, C.; Cardinale, E.; Ramasindrazana, B.; Dietrich, M.; Goodman, S.M.; Tortosa, P.; Dellagi, K. Identification of Tenrec ecaudatus, a wild mammal introduced to Mayotte Island, as a reservoir of the newly identified human pathogenic Leptospira mayottensis. PLoS Negl. Trop. Dis. 2016, 10, e0004933. [CrossRef]

20. Barragán, V.; Chiriboga, J.; Miller, E.; Olivas, S.; Birdsell, D.; Hepp, C.; Hornstra, H.; Schupp, J.M.; Morales, M.; Gonzalez, M.G.; et al. High Leptospira diversity in animals and humans complicates the search for common reservoirs of human disease in rural Ecuador. PLoS Negl. Trop. Dis. 2016, 10, e0004990. [CrossRef] [PubMed]

21. Guernier, V.; Lagadec, E.; Cordonin, C.; Le Minter, G.; Gomard, Y.; Pagès, F.; Jaffar-Bandjee, M.-C.; Michault, A.; Tortosa, P.; Dellagi, K. Human leptospirosis on Reunion Island, Indian Ocean: Are rodents the (only) ones to blame? PLoS Negl. Trop. Dis. 2016, 10, e0004733. [CrossRef]

22. Ratet, G.; Veyrier, F.J.; D'Andon, M.F.; Kammerscheit, X.; Nicola, M.-A.; Picardeau, M.; Boneca, I.G.; Werts, C. Live Imaging of Bioluminescent Leptospira interrogans in mice reveals renal colonization as a stealth escape from the blood defenses and antibiotics. PLoS Negl. Trop. Dis. 2014, 8, e3359. [CrossRef]

23. Ashford, R. When is a reservoir not a reservoir? Emerg. Infect. Dis. 2001, 9, 1495-1496. [CrossRef] [PubMed]

24. Gomes-Solecki, M.; Santecchia, I.; Werts, C. Animal models of leptospirosis: Of mice and hamsters. Front. Immunol. 2017, 8, 58. [CrossRef]

25. Matsui, M.; Goarant, C.; Moniquet, V.; Roudier, M.; Roche, L.; Soupé-Gilbert, M.-E. Experimental hamster infection with a strain of Leptospira borgpetersenii Ballum isolated from a reservoir mouse in New Caledonia. Am. J. Trop. Med. Hyg. 2015, 92, 982-985. [CrossRef] [PubMed]

26. Wunder, E.A.; Figueira, C.P.; Santos, G.R.; Lourdault, K.; Matthias, M.A.; Vinetz, J.M.; Ramos, E.; Haake, D.A.; Picardeau, M.; dos Reis, M.G.; et al. Real-Time PCR reveals rapid dissemination of Leptospira interrogans after intraperitoneal and conjunctival inoculation of hamsters. Infect. Immun. 2016, 84, 2105-2115. [CrossRef] [PubMed]

27. Cordonin, C.; Turpin, M.; Bascands, J.-L.; Dellagi, K.; Mavingui, P.; Tortosa, P.; Roche, M. Three Leptospira strains from Western Indian Ocean wildlife show highly distinct virulence phenotypes through hamster experimental infection. Front. Microbiol. 2019, 10, 382. [CrossRef] [PubMed]

28. Ristow, P.; Bourhy, P.; Kerneis, S.; Schmitt, C.; Prevost, M.-C.; Lilenbaum, W.; Picardeau, M. Biofilm formation by saprophytic and pathogenic leptospires. Microbiology 2008, 154, 1309-1317. [CrossRef] [PubMed]

29. Lloyd-Smith, J.; Greig, D.J.; Hietala, S.; Ghneim, G.S.; Palmer, L.; Leger, J.S.; Grenfell, B.T.; Gulland, F.M. Cyclical changes in seroprevalence of leptospirosis in California sea lions: Endemic and epidemic disease in one host species? BMC Infect. Dis. 2007, 7, 125. [CrossRef]

30. Musso, D.; La Scola, B. Laboratory diagnosis of leptospirosis: A challenge. J. Microbiol. Immunol. Infect. 2013, 46, 245-252. [CrossRef]

31. Roberts, M.W.; Smythe, L.; Dohnt, M.; Symonds, M.; Slack, A. Serologic-based investigation of leptospirosis in a population of free-ranging Eastern grey kangaroos (Macropus giganteus) indicating the presence of Leptospira weilii Serovar Topaz. J. Wildl. Dis. 2010, 46, 564-579. [CrossRef] [PubMed]

32. Assenga, J.A.; Matemba, L.E.; Muller, S.K.; Mhamphi, G.G.; Kazwala, R.R. Predominant leptospiral serogroups circulating among Humans, livestock and wildlife in Katavi-Rukwa ecosystem, Tanzania. PLoS Negl. Trop. Dis. 2015, 9, e0003607. [CrossRef]

33. Andersen-Ranberg, E.U.; Pipper, C.B.; Jensen, P.M. Global patterns of Leptospira prevalence in vertebrate reservoir hosts. J. Wildl. Dis. 2016, 52, 468-477. [CrossRef] [PubMed]

34. Sigaud, M.; Caceres, S.; Picard, M.; Desvars, A.; Michault, A. Tailless tenrec (Tenrec ecaudatus): Natural maintenance host of leptospires? Bull. Soc. Pathol. Exot. 2009, 102, 19-20. [CrossRef]

35. Desvars, A.; Naze, F.; Vourc'H, G.; Michault, A.; Cardinale, E.; Bourhy, P.; Picardeau, M. Similarities in Leptospira Serogroup and species distribution in animals and Humans in the Indian Ocean Island of Mayotte. Am. J. Trop. Med. Hyg. 2012, 87, 134-140. [CrossRef] [PubMed]

36. Ellis, W.; O'Brien, J.; Cassells, J. Role of cattle in the maintenance of Leptospira interrogans serotype hardjo infection in Northern Ireland. Vet. Rec. 1981, 108, 555-557. [CrossRef] 
37. Miraglia, F.; Moreno, A.M.; Gomes, C.R.; Paixão, R.; Liuson, E.; Morais, Z.M.; Maiorka, P.; Seixas, F.K.; Dellagostin, O.A.; Vasconcellos, S.A. Isolation and characterization of Leptospira interrogans from pigs slaughtered in São Paulo State, Brazil. Braz. J. Microbiol. 2008, 39, 501-507. [CrossRef] [PubMed]

38. Libonati, H.; Pinto, P.S.; Lilenbaum, W. Seronegativity of bovines face to their own recovered leptospiral isolates. Microb. Pathog. 2017, 108, 101-103. [CrossRef] [PubMed]

39. Sant'Anna, R.; Vieira, A.S.; Grapiglia, J.; Lilenbaum, W. High number of asymptomatic dogs as leptospiral carriers in an endemic area indicates a serious public health concern. Epidemiol. Infect. 2017, 145, 1852-1854. [CrossRef]

40. Dietrich, M.; Gomard, Y.; Lagadec, E.; Ramasindrazana, B.; Le Minter, G.; Guernier, V.; Benlali, A.; Rocamora, G.; Markotter, W.; Goodman, S.M.; et al. Biogeography of Leptospira in wild animal communities inhabiting the insular ecosystem of the western Indian Ocean islands and neighboring Africa. Emerg. Microbes Infect. 2018, 7, 1-12. [CrossRef]

41. Gomard, Y.; Dietrich, M.; Wieseke, N.; Ramasindrazana, B.; Lagadec, E.; Goodman, S.M.; Dellagi, K.; Tortosa, P. Malagasy bats shelter a considerable genetic diversity of pathogenic Leptospira suggesting notable host-specificity patterns. FEMS Microbiol. Ecol. 2016, 92. [CrossRef] [PubMed]

42. Desvars, A.; Naze, F.; Benneveau, A.; Cardinale, E.; Michault, A. Endemicity of leptospirosis in domestic and wild animal species from Reunion Island (Indian Ocean). Epidemiol. Infect. 2012, 141, 1154-1165. [CrossRef]

43. Pagès, F.; Larrieu, S.; Simoes, J.; Lenabat, P.; Kurtkowiak, B.; Guernier, V.; LE Minter, G.; Lagadec, E.; Gomard, Y.; Michault, A.; et al. Investigation of a leptospirosis outbreak in triathlon participants, Réunion Island, 2013. Epidemiol. Infect. 2015, 144, 661-669. [CrossRef] [PubMed]

44. Cox, T.E.; Smythe, L.D.; Leung, L.K.-P. Flying foxes as carriers of pathogenic Leptospira species. J. Wildl. Dis. 2005, 41, 753-757. [CrossRef] [PubMed]

45. Hamond, C.; Martins, G.; Loureiro, A.P.; Pestana, C.; Lawson-Ferreira, R.; Medeiros, M.A.; Lilenbaum, W. Urinary PCR as an increasingly useful tool for an accurate diagnosis of leptospirosis in livestock. Vet. Res. Commun. 2013, 38, 81-85. [CrossRef] [PubMed]

46. Cilia, G.; Bertelloni, F.; Coppola, F.; Turchi, B.; Biliotti, C.; Poli, A.; Parisi, F.; Felicioli, A.; Cerri, D.; Fratini, F. Isolation of Leptospira serovar Pomona from a crested porcupine (Hystrix cristata, L., 1758). Vet. Med. Sci. 2020, 6, 985-991. [CrossRef]

47. Blackmore, D.K.; Schollum, L.M.; Moriarty, K.M. The magnitude and duration of titres of leptospiral agglutinins in human sera. N. Z. Med. J. 1984, 97, 83-86.

48. Lupidi, R.; Cinco, M.; Balanzin, D.; Delprete, E.; Varaldo, P. Serological follow-up of patients involved in a localized outbreak of leptospirosis. J. Clin. Microbiol. 1991, 29, 805-809. [CrossRef]

49. Cumberland, P.; Everard, C.O.; Wheeler, J.G.; Levett, P.N. Persistence of anti-leptospiral IgM, IgG and agglutinating antibodies in patients presenting with acute febrile illness in Barbados 1979-1989. Eur. J. Epidemiol. 2001, 17, 601-608. [CrossRef] [PubMed]

50. Cordonin, C.; Turpin, M.; Bringart, M.; Bascands, J.-L.; Flores, O.; Dellagi, K.; Mavingui, P.; Roche, M.; Tortosa, P. Pathogenic Leptospira and their animal reservoirs: Testing host specificity through experimental infection. Sci. Rep. 2020, 10, 1-8. [CrossRef] [PubMed]

51. Biscornet, L.; Dellagi, K.; Pagès, F.; Bibi, J.; De Comarmond, J.; Mélade, J.; Govinden, G.; Tirant, M.; Gomard, Y.; Guernier, V.; et al. Human leptospirosis in Seychelles: A prospective study confirms the heavy burden of the disease but suggests that rats are not the main reservoir. PLoS Negl. Trop. Dis. 2017, 11, e0005831. [CrossRef] 